\title{
Epidemiology of non-transfusion dependent thalassaemias: an emerging global concern
}

\section{Androulla Eleftheriou}

\section{Thalassaemia International Federation, Nicosia, Cyprus}

\section{Oral presentation}

Oral presentation is available online

\author{
Correspondence: Androulla Eleftheriou \\ CC Copyright A. Eleftheriou, 2013 \\ Licensee PAGEPress, Italy \\ Thalassemia Reports 2013; 3(s1):e9 \\ doi:10.4081/thal.2013.s1.e9
}

This article is distributed under the terms of the Creative Commons Attribution Noncommercial License (by-nc 3.0) which permits any noncommercial use, distribution, and reproduction in any medium, provided the original author(s) and source are credited.

\section{Parts of this work were presented at the}

" 3 rd Pan-European Conference on Haemoglobinopathies and Rare Anaemias", Limassol (Cyprus), 24-26 October 2012. 